ISSN 0258-7122

Bangladesh J. Agril. Res. 35(3) : 535-541, September 2010

\title{
INHERITANCE OF TIP STERILITY IN RELATION TO AURICLE PIGMENTATION AND WAXY BLOOM IN THREE CROSSES OF HEXAPLOID WHEAT (Triticum aestivum L.)
}

\author{
R. PARVEEN ${ }^{1}$, M. M. UD-DEEN ${ }^{2}$ AND G. KABIR ${ }^{3}$
}

\begin{abstract}
Two Bangladeshi varieties, Aghrani and Ananda were found with normal spikes, pink auricle and non-waxy blooms. The variety Akbar resembled these characters except the auricle colour, where it was white. On the contrary, the selected line FM-147 was found with tip sterile, white auricle, and waxy bloom characters. The $\mathrm{F}_{1} \mathrm{~s}$ in three different crosses (AG $\times$ FM-147, AN $\times$ FM-147) were found with normal spikes, white auricle, and non-waxy bloom. The $\mathrm{F}_{1}$ population of three crosses were found to segregate in the proportion of 3:1 with normal and tip sterile plants. Backcross progenies were found to segregate into 1:1 ratio with normal and tip sterile plants. These results indicated that a recessive gene controls the tip sterility. The auricle pigmentation in $\mathrm{F}_{2} \mathrm{~S}$ of the crosses between AG $\times$ FM-147 and AN $\times$ FM- 147 was found to show the ratio 3:1 with auricle of pink and white pigmentation. Backcross progenies showed also the ratio 1:1. The inheritance of auricle pigmentation was also found to be governed by a single recessive gene. The $\mathrm{F}_{2} \mathrm{~S}$ in three crosses showed the ratio 3:1 with waxy bloom and non- waxy bloom. Backcross progenies showed also the ratio 1:1 for these two characters. The $F_{2}$ populations for two characters at a time were found to segregate into a dihybrid ratio of 9:3:3:1 indicating the absence of any linkage between these two characters.
\end{abstract}

Keywords: Inheritance, tip sterility, hexaploid wheat.

\section{Introduction}

In Bangladesh, wheat had no place as a food crop before 1970. But now it is the second most important cereal crop and playing a vital role in Agricultural economy of Bangladesh. This is why, massive expansion in production of high yielding varieties has been undertaken in different research institutes and at farmers' level of Bangladesh to solve the food problem.

The inheritance of quantitative characters of wheat have been reported by several workers (Wehrhahn, 1986; Joshi and Singh, 1988; Jackson et al., 1978. Many characters of quality traits of wheat have been studied genetically (Ausemus, 1986; Ausemus et al., 1984; Matsuura, 1973; Sears, 1988). Inheritance pattern in wheat is complex because of the multiple genomes. In the

${ }^{1}$ M. Sc. Student, Dept. of Botany, University of Rajshahi, Rajshahi, ${ }^{2}$ Associate Professor, Dept. of Crop Science \& Technology, University of Rajshahi, Rajshahi, ${ }^{3}$ Professor, Dept. of Botany, University of Rajshahi, Rajshahi, Bangladesh. 
hexaploid group, there may be three pairs of factors that condition similar characters, one pair in each of the three genomes. Instance of duplicate and triplicate factors in wheat have been reported (Ausemus et al., 1984).

Apical sterility is such a character, which is also omitted because of its inconsistent genetic expression. This character is undesirable due to death of the terminal spikelets and work on this character is very much scanty. Till to day, only Shoran and Joshi (1987) have reported inheritance of apical sterility in relation to marker characters in wheat. They observed this character in one of the new wheat strains developed at Vivekananda Pravatiya Krishi Anusandhan Shala, India. Apical sterility is being observed for the last few years in one of the grass dwarf selected lines of wheat (supplied from the Department of Agricultural and Environmental Sciences, University of Newcastle Upoin Tyne, U.K.). Professor Golam Kabir with his research students of Cytogenetics Laboratory of the Department of Botany, Rajshahi University on apparent observation found this trait to inherit inconsistently from generation to generation.

Since this tip sterility is an undesirable attribute, the present study was conducted with this tip sterile line of wheat and its progenies to know its mode of inheritance.

\section{Materials and Method}

Seeds of three Bangladeshi varieties and one tip sterile selected line of hexaploid wheat (Triticum aestivum L.) along with their hybrid progenies were used as plant material. These seeds were supplied from Cytogenetics Laboratory, Department of Botany, University of Rajshahi, Rajshahi, Bangladesh. A short description of the experimental materials is given below:

The plants of each variety or lines and their hybrid progenies were grown in the experimental field of Rajsbahi University following recommended agronomic practices.

The field was laid out in a split-plot design with three replications. Three crosses were placed in the main plots and replications in the subplots. Each subplot included 27 rows of plants, three rows for each parent, $\mathrm{F}_{1}$ and $\mathrm{BC}_{1}$, and 15 rows for $F_{2}$ generations. Genotypes were assigned randomly to rows. Distance between the rows was $30 \mathrm{~cm}$ and between plants within rows was $10 \mathrm{~cm}$. Each row was $1.10 \mathrm{~m}$ long and comprised 12 plants. The space between plots and around the field was $50 \mathrm{~cm}$. Each plot size was $7.8 \times 1.1 \mathrm{~m}$ and the field was 8.8 $\times 5.5 \mathrm{~m}$ and surrounded by one non-experimental plants line. The mean values recorded against all the treatments were analyzed statistically. 


\begin{tabular}{|c|c|c|}
\hline $\begin{array}{l}\text { Varieties/Lines and } \\
\text { Progenies }\end{array}$ & Sources & Character \\
\hline Aghrani (AG) & $\begin{array}{l}\text { Regional Agricultural } \\
\text { Research Station, Ishurdi, } \\
\text { Pabna, Bangladesh. }\end{array}$ & $\begin{array}{l}\text { Normal spikes, pink } \\
\text { auricle, non-waxy } \\
\text { bloom. }\end{array}$ \\
\hline Akbar (AK) & -do- & $\begin{array}{l}\text { Normal spikes, white } \\
\text { auricle, non-waxy } \\
\text { bloom. }\end{array}$ \\
\hline Ananda (AN) & -do- & $\begin{array}{l}\text { Nonnal spikes, pink } \\
\text { auricle, non-waxy } \\
\text { bloom. }\end{array}$ \\
\hline FM-147 & $\begin{array}{l}\text { Dept. of Agriculture and } \\
\text { Environmental Sciences, } \\
\text { University of Newcastle } \\
\text { Upon Tyne, U.K. }\end{array}$ & $\begin{array}{l}\text { Tip sterile, white } \\
\text { auricle, waxy bloom. }\end{array}$ \\
\hline $\mathrm{F}_{1}(\mathrm{AGXFM-147)}$ & $\begin{array}{l}\text { Cytogenetics Laboratory, } \\
\text { Dept. of Botany, } \\
\text { University of Rajshalu, } \\
\text { Rajshahi, Bangladesh. }\end{array}$ & - \\
\hline $\mathrm{F}_{1}(\mathrm{AKXFM}-147)$ & -do- & - \\
\hline $\mathrm{F}_{1}(\mathrm{ANXFM-147)}$ & -do- & - \\
\hline $\mathrm{F}_{2}(\mathrm{AGXFM-147)}$ & -do- & - \\
\hline $\mathrm{F}_{2}(\mathrm{AKXFM-147)}$ & -do- & - \\
\hline $\mathrm{F}_{2}(\mathrm{ANXFM-147)}$ & -do- & - \\
\hline $\mathrm{BC}_{1}\left(\mathrm{AGF}_{1} \mathrm{XFM}-147\right)$ & -do- & - \\
\hline $\mathrm{BC}_{1}\left(\mathrm{AKF}_{1} \mathrm{XFM}-147\right)$ & -do- & - \\
\hline $\mathrm{BC}_{1}\left(\mathrm{ANF}_{1} \mathrm{XFM}-147\right)$ & -do- & - \\
\hline
\end{tabular}

\section{Results and Discussion}

The results obtained from the present study are described under the following heads.

\section{Inheritance of tip sterility in relation to marker characters}

The $F_{1} S$ of three different crosses, such as Aghrani $\times$ FM-147, Akbar $\times$ FM-147, and Ananda $\times$ FM-147 were found with normal spikes, white auricle, and nonwaxy bloom. These characters were considered to be dominant. On the other hand, tip sterility, pink auricle, and waxy bloom were considered as recessive characters due to their mode of inheritance. Prior to make it confirm, all the parents used in this study were examined carefully. The Bangladeshi varieties Aghrani and Ananda were found with normal spikes, pink auricle, and non-waxy blooms. The variety Akbar resembled all these characters except the auricle colour, where it was white. On the contrary, the selected line FM-147 was found with tip sterility, white auricle, and waxy bloom characters. Thus, during the growing period of $F_{1} s$ in 
experimental field, back cross progenies were also examined and they resembled fairly the respective $F_{1} S$ of all the crosses. The resemblances in case of the above mentioned characters between $F_{1}$ and backcross progenies helped make it confirm that tip sterility, pink auricle pigmentation, and waxy bloom characters are recessive. For the segregation study of these three recessive characters, data were recorded and those are presented in Table 1.

Table 1. Segregation for tip sterility, auricle pigmentation and waxy bloom in $F_{2}$ and back cross generations of three crosses of wheat.

\begin{tabular}{|c|c|c|c|c|c|c|c|c|c|}
\hline \multirow{2}{*}{ Cross } & \multirow{2}{*}{$\begin{array}{c}\text { Genera } \\
\text {-tion }\end{array}$} & \multirow{2}{*}{$\begin{array}{c}\text { Charac- } \\
\text { ters }\end{array}$} & \multicolumn{2}{|c|}{$\begin{array}{c}\text { No. of plants } \\
\text { observed }\end{array}$} & \multicolumn{2}{|c|}{$\begin{array}{c}\text { No. of plants } \\
\text { expected }\end{array}$} & \multirow{2}{*}{$f \mathrm{x}^{2}$} & \multirow{2}{*}{ P-Value } & \multirow{2}{*}{$\begin{array}{l}\text { Mode of } \\
\text { segregation }\end{array}$} \\
\hline & & & \begin{tabular}{|c|} 
Domi- \\
nant
\end{tabular} & $\begin{array}{l}\text { Rece- } \\
\text { ssive }\end{array}$ & \begin{tabular}{|c|}
$\begin{array}{c}\text { Domin- } \\
\text { ant }\end{array}$ \\
\end{tabular} & $\begin{array}{l}\text { Rece- } \\
\text { ssive }\end{array}$ & & & \\
\hline $\begin{array}{l}\text { Ag x } \\
\text { FM-147 }\end{array}$ & $\mathrm{F}_{2}$ & TS & 94 & 26 & 90.00 & 30.00 & 0.17 & $0.50-0.30$ & $3 \mathrm{~N}: 1 \mathrm{TS}$ \\
\hline $\begin{array}{l}F_{1} X \\
F M-147\end{array}$ & $\mathrm{BC}_{1}$ & TS & 17 & 12 & 14.50 & 14.50 & 0.86 & $0.50-0.30$ & IN: 1 TS \\
\hline $\begin{array}{l}\text { Ak x } \\
\text { FM-147 }\end{array}$ & $\mathrm{F}_{2}$ & TS & 93 & 24 & 87.75 & 29.25 . & 1.25 & $0.30-0.20$ & $3 \mathrm{~N}: 1 \mathrm{TS}$ \\
\hline $\begin{array}{l}F_{1} x \\
\text { FM-147 }\end{array}$ & $\mathrm{BC}_{1}$ & TS & 17 & 12 & 14.50 & 14.50 & 0.86 & $0.50-0.30$ & IN: 1 TS \\
\hline $\begin{array}{l}\text { An x } \\
\text { FM-147 }\end{array}$ & $\mathrm{F}_{2}$ & TS & 88 & 32 & 90.00 & 30.00 & 0.30 & $0.70-0.30$ & $3 \mathrm{~N}: 1 \mathrm{TS}$ \\
\hline $\begin{array}{l}F_{1} x \\
\text { FM- } 147\end{array}$ & $\mathrm{BC}_{1}$ & TS & 17 & 13 & 15.00 & 15.00 & 0.52 & $0.50-0.30$ & IN: 1 TS \\
\hline $\begin{array}{l}\text { Ag x } \\
\text { FM-147 }\end{array}$ & $\mathrm{F}_{2}$ & $\mathrm{AP}$ & 87 & 33 & 90.00 & 30.00 & 0.40 & $0.70-0.50$ & $3 \mathrm{~W}: 1 \mathrm{AP}$ \\
\hline $\begin{array}{l}F_{1} x \\
\text { FM-147 }\end{array}$ & $\mathrm{BC}_{1}$ & AP & 18 & 11 & 14.50 & 14.50 & 1.68 & $0.20-0.10$ & $1 \mathrm{~W}: 1 \mathrm{AP}$ \\
\hline $\begin{array}{l}\text { An x } \\
\text { FM-147 }\end{array}$ & $\mathrm{F}_{2}$ & $\mathrm{AP}$ & 85 & 37 & 90.00 & 30.00 & 1.11 & $0.30-0.20$ & $3 \mathrm{~W}: 1 \mathrm{AP}$ \\
\hline $\begin{array}{l}F_{1} x \\
\text { FM-147 }\end{array}$ & $\mathrm{BC}_{1}$ & $\mathrm{AP}$ & 19 & 11 & 15.00 & 15.00 & 2.13 & 0.20-. 10 & $1 \mathrm{~W}: 1 \mathrm{AP}$ \\
\hline $\begin{array}{l}\text { Ag x } \\
\text { FM-147 }\end{array}$ & $\mathrm{F}_{2}$ & WB & 85 & 35 & 90.00 & 30.00 & 1.11 & $0.30-0.20$ & 3NWB: I WB \\
\hline $\begin{array}{l}F_{1} x \\
\text { FM- } 147\end{array}$ & $\mathrm{BC}_{1}$ & WB & 16 & 13 & 14.50 & 14.50 & 0.31 & $0.70-0.50$ & 1NWB: $1 \mathrm{WB}$ \\
\hline $\begin{array}{l}\text { Ak x } \\
\text { FM-147 }\end{array}$ & $\mathrm{F}_{2}$ & WB & 90 & 27 & 87.75 & 29.25 & 0.22 & $0.70-0.50$ & 3NWB: $1 \mathrm{WB}$ \\
\hline $\begin{array}{l}F_{1} x \\
\text { FM-147 }\end{array}$ & $\mathrm{BC}_{1}$ & WB & 16 & 14 & 15.00 & 15.00 & 0.13 & $0.30-0.20$ & INWB: I WB \\
\hline $\begin{array}{l}\text { An x } \\
\text { FM-147 }\end{array}$ & $\mathrm{F}_{2}$ & WB & 92 & 28 & 90.00 & 30.00 & 0.17 & $0.70-0.50$ & 3NWB: $1 \mathrm{WB}$ \\
\hline $\begin{array}{l}F_{1} x \\
\text { FM-147 }\end{array}$ & $\mathrm{BC}_{1}$ & WB & 16 & 14 & 15.00 & 15.00 & 0.13 & $0.80-0.70$ & 1NWB: $1 \mathrm{WB}$ \\
\hline
\end{tabular}

$\mathrm{N}=$ Normal, $\mathrm{W}=$ White, $\mathrm{NWB}=$ Non Waxy Bloom, $\mathrm{TS}=$ Tip Sterility, $\mathrm{AP}=$ Auricle Pigmentation, $\mathrm{WB}=$ Waxy Bloom. 
The $F_{2}$ population of the three crosses were found to segregate in the proportion of 3:1 with normal and tip sterile plants. Backcross progenies were found to segregate into 1:1 ratio with normal and tip sterile plants. These results indicated the recessive gene control of the tip sterility in the selected line FM147.

\section{Inheritance of auricle pigmentation}

This character in $\mathrm{F}_{2} \mathrm{~S}$ of the crosses between Aghrani $\times$ FM-147 and Ananda $\times$ FM-147 was found to show the ratio 3:1 with auricle of pink and white pigmentation. Back cross progenies showed also the ratio 1:1. The inheritance of pink auricle in Aghrani and Ananda was found to govern by a single recessive gene.

\section{Inheritance of waxy bloom}

Like apical sterility and pink auricle, the inheritance of waxy bloom was also found to govern by a single recessive gene. Data on both $F_{2}$ and back cross progenies indicated the inheritance of waxy bloom in the single monohybrid ratio in all the three crosses.

\section{Relationship between tip sterility, auricle pigmentation and waxy bloom}

To study the relationship between these three characters, $F_{2}$ data were classified into 4 classes and these are shown in Table 2. The plants showing the absence of tip sterility, auricle pigmentation, and waxy bloom were categorized as normal and the remaining 3 classes were formed on the basis of the presence of either one or both the characters. The $\mathrm{F}_{2}$ populations for two characters at a time were found to segregate into a dihybrid ratio of 9:3:3:1 indicating the absence of any linkage between these two characters.

Since tip sterility is an undesirable trait and there is no more information about its mode of inheritance, this experiment was conducted considering two marker characters. In the present study, $F_{2}$ populations in three crosses of wheat segregated into 3:1 ratio of plants with normal and tip sterile spikes. Further, the segregation in the first back cross progenies in a ratio of 1:1 indicated the single recessive gene control of tip sterility in the selected line FM-147. The segregation ratios for auricle pigmentation and waxy bloom in both the $F_{2}$ and back cross progenies indicated the presence of single recessive gene to govern these two characters in Aghrani, Ananda, and FM-147 successively. However, Shaoran and Joshi (1987) found the inheritance of tip sterility and auricle pigmentation to be governed by single recessive gene, but that of waxy bloom by two recessive complement genes. Inheritance of many characters in wheat is somewhat complex because of the multiple genomes. Numerous instances of single, double or triple factors in wheat have been reported. Red kernel colour in wheat is 
dominant over white and its inheritance with the ratios of 3:1, 15:1, and 63:1 generally have been obtained in $\mathrm{F}_{2}$ generation indicating the presence of one, two or three factors. Glume colour usually segregates into a 3:1 ratio of red or brown versus white but a 15:1 ratio of brown to white glumes was reported (Love and Craig, 1989).

Table 2. Segregation for two characters at a time in the $F_{2}$ generations of three different crosses of wheat.

\begin{tabular}{|c|c|c|c|c|c|c|c|}
\hline Generation & Characters & Class & $\begin{array}{l}\text { Observed } \\
\text { frequency }\end{array}$ & $\begin{array}{l}\text { Expected } \\
\text { frequence }\end{array}$ & $f x^{2}$ & P-value & $\begin{array}{c}\text { Mode of } \\
\text { segregation }\end{array}$ \\
\hline \multirow{4}{*}{$\begin{array}{l}F_{2}(A g \times \text { FM- } \\
147)\end{array}$} & TS & 1. Normal & 72 & 67.50 & \multirow{4}{*}{0.71} & \multirow{4}{*}{$0.90-0.80$} & \multirow{4}{*}{$\begin{array}{l}\text { 9N:3TS:3AP: } \\
\text { ITS. AP }\end{array}$} \\
\hline & VS & 2. TS & 20 & 22.50 & & & \\
\hline & \multirow{2}{*}{ AP } & 3. AP & 21 & 22.50 & & & \\
\hline & & 4. TS with pig. & 7 & 7.50 & & & \\
\hline \multirow{4}{*}{$\begin{array}{l}F_{2}(\text { An } x \text { FM- } \\
147)\end{array}$} & TS & 1. Normal & 70 & 67.50 & \multirow{4}{*}{1.73} & \multirow{4}{*}{$0.70-0.50$} & \multirow{4}{*}{$\begin{array}{l}\text { 9N:3TS:3AP:1 } \\
\text { TS.AP }\end{array}$} \\
\hline & VS & 2. TS & 19 & 22.50 & & & \\
\hline & \multirow{2}{*}{ AP } & 3. AP & 25 & 22.50 & & & \\
\hline & & 4. TS with pig. & 5 & 7.50 & & & \\
\hline \multirow{4}{*}{$\begin{array}{l}\mathrm{F}_{2}(\mathrm{Ag} \times \mathrm{FM}- \\
147)\end{array}$} & TS & 1. Normal & 66 & 67.50 & \multirow{4}{*}{2.34} & \multirow{4}{*}{$0.70-0.50$} & \multirow{4}{*}{$\begin{array}{l}\text { 9N:3TS:3WB: } \\
\text { ITS. WB }\end{array}$} \\
\hline & VS & 2. TS & 26 & 22.50 & & & \\
\hline & \multirow{2}{*}{ WB } & 3. WB & 18 & 22.50 & & & \\
\hline & & 4. TS with WB & 10 & 7.50 & & & \\
\hline \multirow{4}{*}{$\begin{array}{l}F_{2}(\mathrm{Ak} \times \mathrm{FM}- \\
147)\end{array}$} & TS & 1. Normal & 60 & 67.50 & \multirow{4}{*}{3.37} & \multirow{4}{*}{$0.50-0.30$} & \multirow{4}{*}{$\begin{array}{l}\text { 9N:3TS:3WB: } \\
\text { ITS. WB }\end{array}$} \\
\hline & VS & 2. TS & 22 & 22.50 & & & \\
\hline & \multirow{2}{*}{ WB } & 3. WB & 30 & 22.50 & & & \\
\hline & & 4. TS with WB & 8 & 7.50 & & & \\
\hline \multirow{4}{*}{$\begin{array}{l}\mathrm{F}_{2}(\mathrm{An} \times \mathrm{FM}- \\
147)\end{array}$} & TS & 1. Normal & 65 & 67.50 & \multirow{4}{*}{2.72} & \multirow{4}{*}{$0.50-0.30$} & \multirow{4}{*}{$\begin{array}{l}\text { 9N:3TS:3WB: } \\
\text { ITS.WB }\end{array}$} \\
\hline & VS & 2. TS & 18 & 22.50 & & & \\
\hline & \multirow{2}{*}{ WB } & 3. WB & 27 & 22.50 & & & \\
\hline & & 4. TS with WB & 10 & 7.50 & & & \\
\hline
\end{tabular}

$\mathrm{N}=$ Normal, $\mathrm{TS}=$ Tip sterility, $\mathrm{AP}=$ Auricle pigmentation, $\mathrm{WB}=$ Waxy bloom, Pig. $=$ Pigmentation.

In the present study, auricle pigmentation was found in the Bangladeshi varieties Aghrani and Ananda and this character was found to be governed by single recessive gene. Auricle colour is sometimes used as descriptor but because of its unreliable expression it is often omitted (Zeven, 1985). Probably, owing to the instability of its expression, only a few reports on its genetics have been established (Pokhryal and Kohli, 1986; Welsh, 1980; Zeven, 1985). However, the present findings on the inheritance of auricle colour are in close agreement of the fmdings of Shoran and Joshi (1987).

While classifying the $\mathrm{F}_{2}$ data into 4 classes for the study of linkage relationship between tip sterility, auricle pigmentation and waxy bloom, the $F_{2}$ 
populations for two characters at a time were found to segregate into dihybrid ratio of 9:3:3:1. These fmdings indicated the absence of any linkage between these characters. The joint segregation of tip sterility with auricle pigmentation and waxy bloom in all the crosses showed independent assortment of these characters. However, Shoran and Joshi (1987) found trihybrid segregation ratio of 27:9:21:7 for tip sterility versus waxy bloom and auricle pigmentation. For tip sterility versus auricle pigmentation, they found dihybrid ratio of 9:3:3:1. Hence, in their study, no linkage relationship was found between tip sterility, auricle pigmentation, and waxy bloom. However, it can be stated that the inheritance of tip sterility, auricle pigmentation, and waxy bloom are simple and can be utilized in any genetic background. Thus, the undesirable trait tip sterility can be avoided without loosing other marker characters in selection of segregating populations of wheat.

\section{References}

Ausemus, E.R., J.B. Herrington, L.P. Reitz and W.W. Worzella. 1984. A summary of genetic studies in hexaploid and tetraploid wheats. J. Am. Soc. Agron. 38: 10821099.

Ausemus, E.R. 1986. Weizen (Triticum L.) "Wheat in North America" in Handfuch der pflanzen zuchtung. Berlin: Paul parey. Lieferung 9, Bogen 11-15, pp. 187-216.

Jackson, B.R., Virks and L.A. Synder. 1978. Quantitative inheritance in crosses among four tetraploid wheats. Can. J. Gen. Cyto. 10(1): 33-43.

Joshi, B.C. and D. Singh. 1988. Genetic analysis of quantitative characters in wheat using chromosome deficient lines. Indian J. 28(1): 66-71.

Love, H.H. and W. Craig. 1989. Methods used and results obtained in cereal investigations at the coronell station. J. Am. Soc. Agron. 10: 145-157.

Matsuura, H. 1973. A bibliographical monograph of plant genetics. $2^{\text {nd }}$ Ed. Sapporo, Japan, Hokkaido Imp. U., pp. 419-465.

Pokhryal, S.C. and S.P. Kohli. 1986. Inheritance of yield reaction to brown rust and other characters in intervarietal crosses of Triricum aestivum L. Indian J. Genet. PI. Breed. 22: $173-180$.

Sears, E.R. 1988. The cytology and genetics of wheat and their relatives. Advances in Genetics. Vol. II. pp. 239-270.

Shoran, J. and H.C. Joshi. 1987. Inheritance of apical sterility in relation to marker characters in bread wheat. Indian J. Agric. Sci. 57(2): 71-75.

Wehrhahn, C.F. 1986. The genetic basis for difference in quantitative characters between two varieties of wheat. L. Dis. Abr. 27: 37 1-372.

Welsh, D.R. 1980. Aneuploid stydies. Aneuploid Wheat Newst. 9: 65.

Zeven, A.C. 1985. The genetics of auricle colour of wheat (Triticum aestivum L.). A Review Euphytica 34: 233-236. 